\title{
Anthocyanin-rich Buni-berry (Antidesma bunius) Extract Increases Paraoxonase 1 Gene Expression in BALB/c Mice Fed with a High-fat Diet
}

\author{
Suryani Tawali ${ }^{1}$, Suryani As'ad ${ }^{2}$, Mochammad Hatta ${ }^{3 *}$, Agussalim Bukhari ${ }^{2}$, Nur Khairi ${ }^{4}$, Yusnita Rifai $^{5}$, Ressy Dwiyanti ${ }^{3,6}$ \\ ${ }^{1}$ Department Public Health and Preventive Medicine, Faculty of Medicine, Hasanuddin University, Makassar, INDONESIA. \\ ${ }^{2}$ Department of Nutrition, Faculty of Medicine, Hasanuddin University, Makassar, INDONESIA. \\ ${ }^{3}$ Molecular Biology and Immunology Laboratory, Faculty of Medicine, Hasanuddin University, Makassar, INDONESIA. \\ "College of Pharmaceutical Sciences of STIFA, Makassar, INDONESIA. \\ SPharmaceutical Chemistry Laboratory, Faculty of Pharmacy, Hasanuddin University, Makassar, INDONESIA. \\ ${ }^{6}$ Department of Medical Microbiology, Faculty of Medicine, Tadulako University, Palu, INDONESIA.
}

\begin{abstract}
Objective: The aim of this study was to determine the effectiveness of buni-berry (Antidesma bunius) extract to increase PON1 mRNA expression in BALB/c mice fed with a high-fat diet. Methods: Twenty, thirty-weeks old male BALB/c mice were randomly allocated into four intervention groups; buni berry extract, simvastatin, control-sick and control-normal groups. All groups received high fat diet, except control-normal group which received control normal-diet. The diets were provided for 12 weeks. Treatments were started in all groups at the same time with the administration of the diets. Mice in buni-berry group were treated with oral buni-berry $300 \mathrm{mg} / \mathrm{kgBW} /$ day. In simvastatin group the mice were provided with oral simvastatin $6 \mathrm{mg} / \mathrm{kkBW} /$ day. The mice in control-sick and control-normal group were not received additional treatment. The intervention was conducted in 12 weeks. Mice body weight was measured weekly. Blood samples from tails were examined at the baseline and after12 weeks intervention for PON1 mRNA expression. Expression of PON1 mRNA was analysed by quantitative Real Time Polymerase Chain Reaction (qRT-PCR).
\end{abstract}

Results: The changes mice body weights during interventions in all groups were not significantly different. PON1 mRNA expression was significantly increase in the buni berry extract group and simvastatin group, while in control-sick group the expression was significantly reduced. Conclusion: Oral administration of $300 \mathrm{mg} / \mathrm{kgBW} /$ day of buni-berry extract is effectively increases PON1 expression in BALB/c mice fed with a high fat diet.

Key words: Buni-berry extract, Antidesma bunius, PON1 mRNA, Atherosclerosis, High fat diet.

\section{Correspondence}

Prof. Mochammad Hatta, M.D, Ph.D, Molecular Biology and Immunology Laboratory, Faculty of Medicine, University of Hasanuddin, Makassar, INDONESIA.

Phone: +62-411-586971

Email: hattaram@yahoo.com

DOI: 10.5530/jyp.2019.11.10

\section{INTRODUCTION}

Berries are known as fruits with high anthocyanins content and other polyphenolic compounds that is associated with cardiovascular disease prevention. ${ }^{1}$ Phenolic compounds in berries particularly anthocyanins were found to be effective in the reduction of atherosclerosis process that causes coronary heart disease through inhibition of LDL oxidation and increases HDL efflux. ${ }^{2,3}$ Buni - berries (Antidesma bunius) is a berry-fruit that is native to Southeast Asia and Northern Australia. The fruit in Indonesia is known as buni, whoonee, bunne and many other traditional names. The dark-purple ripe fruits are rich in phenolic compounds particularly flavonoid anthocyanins and high antioxidant capacity. ${ }^{4,5}$ Paraoxonase 1 (PON1) is an HDL associated enzyme, that has recently drown researchers attention on its roles on the prevention of the development and process of atherosclerosis. ${ }^{6}$ Studies by Litvinov et al. ${ }^{7}$ and Lusis et al. ${ }^{8}$ have revealed that PON1 as protein and hydrolyzing enzyme responsible for the most of the antioxidant properties of HDL which prevent LDL and HDL from oxidation. Martini et al. ${ }^{9}$ reported in their review that polyphenolic compounds from fruits and other part of plants can increase expression of PON1 mRNA and concentration of PON1 enzyme. The aim of our study was to demonstrate whether buni-berry
(Antidesma bunius) extract can increase mRNA expression of PON1 in $\mathrm{balb} / \mathrm{c}$ mice fed with a high-fat diet.

\section{MATERIALS AND METHODS}

Animals

Male BALB/c mice aged 6 weeks (15-20 gr) were obtained from Unit Maintenance and Development of Animal Trial Molecular Biology and Immunology Laboratory Faculty of Medicine, Hasanuddin University, Makassar. All the mice were caged in groups of six under environmentally controlled room with $12 \mathrm{~h}$ light/dark cycle and provide standard rodent diet and water ad libitum until further 30 weeks of age. The 30 weeks old mice were then randomly allocated into the four experiment groups that matched for body weight (Table 3).

Diets

Standard diet (control diet) D12102 and high fat diet Clinton/Cybulsky D12109 used, were purchased from Research Diet Inc. USA. The control diet D12102 contained $10 \%$ calory from fat. The high fat diet contained $40 \%$ calory from fat mainly from cocoa butter with $1.25 \%$ cholesterol $(\mathrm{w} / \mathrm{w})$

This is an open access article distributed under the terms of the Creative Commons Attribution-NonCommercial-ShareAlike 4.0 License, which allows others to remix, tweak, and build upon the work non-commercially, as long as the author is credited and the new creations are licensed under the identical terms. 
Table 1: The composition of Clinton/ Cybulsky rodent diet D12102C and D12109C.

\begin{tabular}{|c|c|c|c|c|}
\hline \multirow[t]{2}{*}{ CONTENT } & \multicolumn{2}{|c|}{$\begin{array}{c}\text { D12102C } \\
\text { (CONTROL DIET) }\end{array}$} & \multicolumn{2}{|c|}{$\begin{array}{c}\text { D12109C } \\
\text { (HIGH FAT DIET) }\end{array}$} \\
\hline & Gram & Cal (\%) & gram & Cal (\%) \\
\hline Protein & 19 & 20 & 23 & 20 \\
\hline Carbohydrate & 67 & 70 & 45 & 40 \\
\hline Fat & 4 & 10 & 20 & 40 \\
\hline Total & & 100 & & 100 \\
\hline $\mathrm{Kcal} /$ gram & 3.85 & & 4.5 & \\
\hline Ingredients & Gram & Kcal & Gram & Kcal \\
\hline Casein, Lactic & 200 & 800 & 200 & 800 \\
\hline L-cystein & 3 & 12 & 3 & 12 \\
\hline Corn starch & 375 & 1500 & 212 & 848 \\
\hline Maltodextrin 10 & 125 & 500 & 71 & 284 \\
\hline Sucrose & 200 & 800 & 113 & 452 \\
\hline Cellulose,BW200 & 50 & 0 & 50 & 0 \\
\hline Soybean oil & 25 & 225 & 25 & 225 \\
\hline Cocoa butter & 20 & 180 & 155 & 1395 \\
\hline Mineral mix S10021 & 10 & 0 & 10 & 0 \\
\hline Dicalcium phosphate & 13 & 0 & 13 & 0 \\
\hline Calcium carbonate & 5.5 & 0 & 5.5 & 0 \\
\hline Potassium Citrate & 16.5 & 0 & 16.5 & 0 \\
\hline Vitamin Mix V10001 & 10 & 40 & 10 & 40 \\
\hline Choline bitartrate & 2 & 0 & 2 & 0 \\
\hline Cholesterol & 0 & 0 & 11.25 & 0 \\
\hline Sodium cholate & 0 & 0 & 4.5 & 0 \\
\hline Red Dye, FD\&C\#40 & 0 & 0 & 0.05 & 0 \\
\hline Blue Dye,FD\&C\#1 & 0 & 0 & 0.05 & 0 \\
\hline Yellow Dye, FD\&C\#5 & 0.1 & 0 & 0 & 0 \\
\hline TOTAL & 1055.1 & 4057 & 901.85 & 4056 \\
\hline
\end{tabular}

Source: Research Diet Inc. USA, 2017

and $0.5 \%$ cholic acid $(\mathrm{w} / \mathrm{w}) .{ }^{10}$ The detail composition of the diets used is presented in Table 1.

\section{Plant material}

Overriped, black purple A. bunius were obtained from local farm in District of Malino, South Sulawesi, Indonesia. The berries were then cleaned, washed and packaged in plastic bags and store in freezer at $-20^{\circ} \mathrm{C}$ until used.

\section{Chemicals and Drugs}

Deionized-water was purchased from OneMed Laboratories Inc. Indonesia. Ascorbic, citric and gallic acid, Folin-Ciocalteau reagent, methanol, ethanol, acetone, sodium carbonate, potassium chloride, sodium acetate, 1,1-diphenyl-2-picrylhydrazyl (DPPH) were procured from Merck, Germany. Sodium carboxymethyl cellulose, ethylene-diamine-tetra-acetic acid (EDTA) and Tris-HCl were obtained from Sigma Aldrich, Switzerland. Guanidium thiocyanate was from Fluka Chemie, Switzerland. TritonX-100 was from Roche, Germany. Celite was purchased from Jansen Chimica, Belgium. Enzyme Superscript II reverse transcriptase was purchased from Invitrogen, USA. SYBR Green qRT-PCR Supermix was purchased from Bio-Rad, USA. Simvastatin was obtained from Kimia Farma, Pharmaceuticals, Indonesia. All other chemicals were of analytical grade.

\section{Preparation of buni-berry (Antidesma bunius) extract}

The frozen berries were then extracted with a $70 \%$ ethanol acidified with $0.01 \%$ citric acid at $\mathrm{pH}$ of 4.9 and put in a room with temperature of $26^{\circ} \mathrm{C}$ for about 6 hrs. ${ }^{11}$ The extracts were then filtered on Whatman 415 paper and concentrated using vacuum rotary evaporator (Buchi, Switzerland) until all alcoholic residues were removed.

\section{Buni-berry extract analysis Total phenols}

The extract then was analysed for total phenolic content using FolinCiocalteu method. ${ }^{12}$ Briefly, A volume of $0.5 \mathrm{~mL}$ of the extract $(100 \mu \mathrm{g} / \mathrm{mL})$ was mixed with $2 \mathrm{~mL}$ of the Folin-Ciocalteu reagent (diluted 1:10 with de-ionized water) and were neutralized with $4 \mathrm{~mL}$ of sodium carbonate solution $(7.5 \%, \mathrm{w} / \mathrm{v})$. The reaction mixture was incubated at room temperature for $30 \mathrm{~min}$. The absorbance was measured at $765 \mathrm{~nm}$. The total phenolic contents were determined from the linear equation of a standard curve prepared with gallic acid. The content of total phenolic compounds expressed as $\mathrm{mg} / \mathrm{g}$ gallic acid equivalent (GAE) of extract.

\section{Total anthocyanins}

Total anthocyanins content (TAC) of the buni-berry extract was measured using $\mathrm{pH}$ differential method. ${ }^{13}$ Two samples of extract were weighed to $0.05 \mathrm{~g}$ each. The first sample was mixed with $0.025 \mathrm{M}$ potassium chloride buffer ( $\mathrm{pH} 1.0)$ and the other sample with $0.4 \mathrm{M}$ sodium acetate buffer $\mathrm{pH} 4.5$. Following $2 \mathrm{hrs}$ of incubation at room temperature $\left(\sim 25^{\circ} \mathrm{C}\right)$, the absorbance for each sample was then read versus the buffer solution $\mathrm{pH}$ 1.0 and buffer solution $\mathrm{pH} 4.5$ as the blank at $\lambda=510 \mathrm{~nm}$ (for the cyanidin 3 -glucoside) and $\lambda=700 \mathrm{~nm}$ (for correction factor). The absorbance values were calculated using the equation:

$$
\mathrm{A}=\{(\mathrm{A} 516-\mathrm{A} 700) \mathrm{pH} 1-(\mathrm{A} 516-\mathrm{A} 700) \mathrm{pH} 4.5\}
$$

TAC was expressed as cyanidin-3-glucoside (\% w/w) equivalents, as follows:

$$
\operatorname{TAC}\left(\% \frac{\mathrm{W}}{\mathrm{W}}\right)=\frac{\mathrm{A}}{\epsilon_{1}} \times \mathrm{MW} \times \mathrm{DF} \times \frac{\mathrm{W}}{\mathrm{Wt}} \times 100 \%
$$

where, $\mathrm{A}=$ absorbance value; $\mathrm{MW}$ (molecular weight) $=449.2 \mathrm{~g} \cdot \mathrm{mol}^{-1}$ for cyanidin-3-glucoside (cyd-3-glu); $\mathrm{DF}=$ dilution factor; $\mathrm{V}=$ final volume after dilution; $\mathrm{W}=$ sample weight $(\mathrm{mg}) ; l=$ width of the cuvette $(\mathrm{cm})$; $\varepsilon=26,900 \mathrm{M}$ extinction coefficient in $\mathrm{L} \mathrm{mol}^{-1} \mathrm{~cm}^{-1}$ for cyd-3-glu.

\section{Antioxidant capacity}

The antioxidant capacity of buni-berry extract and of the standard solution (ascorbic acid) were measured using 1,1,-diphenyl-2-picrylhydrazyl (DPPH) method. ${ }^{12,14}$ The mixture of $2 \mathrm{~mL}$ of $1.0 \mathrm{mmol} / \mathrm{L}$ DPPH solution in methanol and $1 \mathrm{~mL}$ of standard solution of extract solution with different concentration $(10-500 \mu \mathrm{g} / \mathrm{mL})$. The mixture solution incubated in dark at $37^{\circ} \mathrm{C}$ for $20 \mathrm{~min}$. The decrease in absorbance of each solution was measured at $517 \mathrm{~nm}$. Ascorbic acid used as positive control while DPPH radical solution was taken as blank. The percentage of radical scavenging activity was measured using formula:

$$
\% \text { free radical scavenging activity }=\frac{\begin{array}{l}
\text { blank absorbancy }- \\
\text { sample absorbancy }
\end{array}}{\text { blank absorbancy }} \times 100 \%
$$


The concentration of sample required to neutralize $50 \%$ of $\mathrm{DPPH}\left(\mathrm{IC}_{50}\right)$ was determined using the curve of percent inhibitions plotted against the respective concentration.

\section{Intervention}

After acclimatization for the new environment (individual cage and new diets), the 30 weeks male BALB/c mice were randomly allocated to four intervention groups with matched body weight. (1) Buni-berry extract (treatment), (2) Simvastatin (control positif), (3) Control sick and (4) Control normal. Each intervention group consisted of five mice.

The mice in the first three intervention groups were fed with a high-fat diet (D12109C), while the mice in control-normal group were fed with control diet (D12102C).

The intervention was conducted for 12 weeks as follows: Every mouse was put in a different individual cage and had free access to diet provided and drinking water. Each mouse in the buni-berry extract group and the simvastatin group respectively received buni-berry extract $300 \mathrm{mg} / \mathrm{kgBW} /$ day $^{15}$ and simvastatin $6 \mathrm{mg} / \mathrm{KgBW} / \mathrm{day}{ }^{16}$ Each, the extract and simvastatin was separately dissolved in sodium carboxymethyl cellulose $5 \%$ solution and delivered orally using ball tip needle to avoid damage in the esophagus or passing through the respiratory tract. In the control-sick group and control-normal group, the mice did not received additional intervention except the high-fat diet and controlnormal diet, respectively.

All mice were weighted weekly, provided and leftover food weighted daily. Blood samples were withdrawn from mouse's tail at baseline (before the intervention was started) and from cardiac puncture at the end of the intervention.

\section{Nucleic acid extraction}

Extraction of nucleid acid was extracted according to the protocol of previous study. ${ }^{17}$ Briefly, lysing, binding and washing were three main steps of this method. One hundred $\mu \mathrm{l}$ of blood sample was dissolved into "L6" solution which is developed from $120 \mathrm{~g}$ guanidiun thyocianate in 100 mL 0.1 M Tris-HCl pH 6.4, 22 mL EDTA pH 8.0 and $2.6 \mathrm{~g}$ Triton X-100. After lysing process the nucleid acid was bound to celitein $50 \mathrm{~mL} \mathrm{H}_{2} \mathrm{O}$ and $500 \mu \mathrm{L}$ of $32 \%(\mathrm{w} / \mathrm{v})$. The solution then was vortexed and centrifuged in effendorf tube $1.5 \mathrm{ml}$ at 13,000 for $15 \mathrm{sec}$. The supernatant was discarded and the sediment left then was washed with $1 \mathrm{ml}$ "L2" solution (guanidium thyocianate and $\mathrm{Tris} \mathrm{HCl} \mathrm{pH} \mathrm{6.4).} \mathrm{The} \mathrm{mixture} \mathrm{then} \mathrm{was}$ vortexed and centrifuged at 13,000 rpm for $15 \mathrm{sec}$, this washing process was repeated twice and continued with $1 \mathrm{~mL}$ ethanol 70\% twice and the last with $1 \mathrm{~mL}$ acetone. The result then was incubated in a water-bath at $56^{\circ} \mathrm{C}$ for 10 minutes. After incubation the sample was added with $60 \mu \mathrm{L}$ "TE" solution (1mM EDTA in $10 \mathrm{mM}$ Tris- $\mathrm{HCl} \mathrm{pH}$ 8.0) then vortexed and centrifuged at 13,000 rpm for $2 \mathrm{~min}$ and incubated in oven for 10 minutes at $56^{\circ} \mathrm{C}$. Following the incubation, the sample was again vortexed and centrifuged at 13,000 rpm for $30 \mathrm{sec}$. The supernatant of this process was obtained and stored at $-80^{\circ} \mathrm{C}$ before RNA analysis.

\section{Analysis of Paraoxonase 1 (PON1) mRNA expression}

PON1 mRNA expression was analysed with Real Time-Quantitative Reverse Transcription Polymerase Chain Reaction (qRT-PCR) using SYBR Green qRT-PCR Supermix (Bio-Rad, USA) and read using RT-PCR machine (BR004129USA, Bio-Rad Laboratories, USA). The following forward and reverse primer were used for PON1: TTCCTTTGTACACAGCAGCG and TGCTGGCTCACAGATTTC respectively ${ }^{18}$ For housekeeping gene $\beta$-actin forward primer was CTCTGGCTCCTAGCACCATGAAGA and reverse primer was GTAA AACGCAGCTCAGTAACAGTCCG. ${ }^{19-20} \mathrm{cDNA}$ templates for use in real time PCR were synthesized from $5 \mu \mathrm{g}$ of total RNA by in vitro transcription in $20 \mu \mathrm{l}$ reaction containing $0.5 \mu \mathrm{g}$ Oligo (dT), $10 \mu \mathrm{M}$ dNTPs and
$1 \mu \mathrm{l}$ of Superscript II reverse transcriptase (Invitrogen, Carlsbad, CA) at $42^{\circ} \mathrm{C}$ for $50 \mathrm{~min}$. Typical real time PCR reaction mixture included the same amount of cDNA templates from RT, 10 pmol of each primers, $25 \mu \mathrm{l}$ iQ SYBR Green Supermix and sterile water in a reaction volume of $50 \mu \mathrm{l}$. The PCR conditions were: $3 \mathrm{~min}$ at $95^{\circ} \mathrm{C}$ followed by 40 cycles at $95^{\circ} \mathrm{C}$ for $30 \mathrm{sec}, 55^{\circ} \mathrm{C}$ for 30 seconds and $68^{\circ} \mathrm{C}$ for $1 \mathrm{~min}$. Relative PON 1 gene expression levels were calculated by subtracting the threshold cycle number $(\mathrm{Ct})$ of the $\beta$-Actin gene from the $\mathrm{Ct}$ of PON1 and raising 2 to the power of this difference. Ct values are defined as the number of PCR cycles at which the fluorescent signal during the PCR reaches a fixed threshold. ${ }^{18}$

\section{Statistical Analysis}

The results are presented as mean \pm SD (standard deviation). The differences between groups are analysed using paired t-test or ANOVA with $\mathrm{p}$-value less than 0.05 is considered significant

\section{Ethics Statement}

The animals were treated following the principles and protocols of The Declaration of Helsinki. The trial was approved by The Committee on the Ethics of Medical Research of University Hasanuddin (Recommendation number: 597/H4.8.4.5.31/PP36-KOMETIK/2017) dated August, 23, 2017.

\section{RESULTS}

\section{The Extract Profiles}

The concentration of total phenolic compounds is $3.42 \%$ and total anthocyanins is $0.83 \%$ (Table 2 ). It means, the extract contained not only anthocyanin, but also other polyphenolic compounds that made up to $3.42 \%$.

The extract showed the ability to neutralize free radicals with antioxidant capacity of $56.46 \mathrm{ppm}$ in term of $\mathrm{IC}_{50}$ (Table 2). Inhibition concentration $50\left(\mathrm{IC}_{50}\right)$ means that the minimal concentration of the extract that can neutralize at least $50 \%$ of the free radicals of 1, 1-diphenyl-2-picrylhydrazyl (DPPH). $\mathrm{IC}_{50}$ of less than $50 \mathrm{ppm}$ is considered as very strong antioxidant capacity, while between 50 to $100 \mathrm{ppm}$ is considered strong.

\section{The mice body weight}

During 12 weeks intervention the mortality rate of the $\mathrm{BALB} / \mathrm{c}$ mice was $2 / 28$. The average weight of mice at the initial intervention and the change of body weight during intervention in four different groups were not significantly different (Table 3 ).

\section{Expression of PON1 mRNA}

The mRNA expression of PON1 enzyme significantly increased in buni berries extract group and simvastatin group (Table 4). On the other hand the expression of PON1 mRNA reduced in the group that was fed with a high fat diet without any intervention (control-sick). In the normal diet (control-normal) group, there was not any significant change in the mRNA expression of paraoxonase 1 (PON1) enzyme.

Table 2: Buni Fruit (Antidesma bunius) extract profiles.

\begin{tabular}{cccc}
\hline $\begin{array}{c}\text { Buni Berry Extract (BBE) } \\
\text { profile }\end{array}$ & Result & Unit & $\begin{array}{c}\text { Measurement } \\
\text { method }\end{array}$ \\
\hline Total phenols & 3.42 & $\%$ & Folin-Ciocalteau \\
Total anthocyanins & 0.83 & $\%$ & $\mathrm{pH}$ differential \\
$\begin{array}{c}\text { Antioxidant capacity } \\
\text { (Radical scavenging activity) }\end{array}$ & $56.46^{*}$ & $\mathrm{ppm}$ & $\mathrm{DPPH}$
\end{tabular}

${ }^{*} \mathrm{IC}_{50}$ (Concentration of the extract required to scavenge $50 \%$ of the free radical $\mathrm{DPPH})$ ) 
Table 3: Body weight of mice at the baseline and after 12 weeks intervention.

\begin{tabular}{cccc}
\cline { 1 - 2 } Groups $^{*}($ Each & \multicolumn{2}{c}{ Body weight $(\mathbf{g})$} & \multirow{2}{*}{$\boldsymbol{p}$ - value } \\
\cline { 1 - 2 } group $\mathrm{n}=\mathbf{5})$ & Baseline & $\mathbf{1 2}$ weeks & \\
\hline Buni berry extract & $36.40 \pm 2.99$ & $36.14 \pm 3.80$ & $0.5^{\mathrm{c}}$ \\
Simvastatin & $37.82 \pm 2.99$ & $37.14 \pm 2.71$ & $0.5^{\mathrm{d}}$ \\
Control-sick & $38.02 \pm 1.09$ & $37.36 \pm 2.75$ & $0.6^{\mathrm{f}}$ \\
Control-normal & $37.86 \pm 2.75$ & $41.66 \pm 3.93$ & $0.4^{\mathrm{g}}$ \\
p-value & $0.8^{\mathrm{a}}$ & $0.08^{\mathrm{b}}$ & \\
\hline
\end{tabular}

${ }^{*}$ Values are means $\pm \mathrm{SD} n=5, p$-value $<0.05$ is considered significant; $\mathrm{a}=p$-value of the different of means body weight at baseline across four intervention groups using ANOVA; $\mathrm{b}=p$-value of the different of means body weight at 12 weeks intervention using ANOVA; c,d,f,g = p-value of the different of means body weight between baseline and 12 weeks intervention using paired $t$ test.

Table 4: Changes of PON1 mRNA expression at baseline and after 12 weeks intervention in the four different intervention groups.

\begin{tabular}{cccccc}
\hline & \multicolumn{5}{c}{ PON1 mRNA expression } \\
\cline { 2 - 6 } $\begin{array}{c}\text { Groups (each } \\
\text { group n = 5) }\end{array}$ & Baseline & 12 Weeks & $\begin{array}{c}\text { Mean } \\
\text { difference }\end{array}$ & $\begin{array}{c}95 \% \\
\text { Confidence } \\
\text { Interval }\end{array}$ & $\begin{array}{c}\boldsymbol{p} \text { - } \\
\text { value }\end{array}$ \\
\hline $\begin{array}{c}\text { Buni berry } \\
\text { extract }\end{array}$ & $6.24 \pm 0.16$ & $6.72 \pm 0.27$ & 0.48 & $0.07 ; 0.90$ & $<0.05$ \\
$\begin{array}{c}\text { Simvastatin } \\
\text { Control-sick }\end{array}$ & $6.33 \pm 0.19$ & $6.83 \pm 0.25$ & 0.5 & $0.05 ; 0.92$ & $<0.05$ \\
$\begin{array}{c}\text { Control- } \\
\text { normal }\end{array}$ & $6.25 \pm 0.13$ & $4.81 \pm 0.30$ & -1.43 & $-1.73 ;-1.13$ & $<0.001$ \\
\hline
\end{tabular}

${ }^{*}$ Values are means $\pm \mathrm{SD} n=5, p$-value $<0.05$ is considered significant

\section{DISCUSSION}

The anthocyanins and total phenolic content of $0.83 \%$ and $3.42 \%$ respectively, is in accordance with previous reports by Butkhup and Samappito. ${ }^{4}$ The buni-berry extract that was used in this study contains anthocyanins and other polyphenolic compounds. As what have been reported by previous studies, anthocyanins and other polyphenolic compounds from fruit demonstrated the ability to prevent atherosclerosis process through improving the expressions and concentrations of markers associated with atherosclerosis process. ${ }^{2,3}$ The present study shows that buni berry extract significantly increased paraoxonase (PON1) mRNA expression. Our study result supports the finding of previous research by Kivici et al. using different fruit extract. ${ }^{20}$ The research demonstrated that the administration of grape seed extract (GSE) at the dose of $100 \mathrm{mg} / \mathrm{kgBW} /$ day, orally, in streptozotocin-induced diabetic rat, for six weeks caused a significant increase in PON1 activitiy compared to the diabetic mice without GSE supplementation. Furthermore, more recent study by Estrada-Luna et al. also reported that another kind of fruit juice (pomegranate juice) supplementation at the dose of $300 \mu \mathrm{l} /$ day that contained $0.35 \mathrm{mmol}$ polyphenols, orally in mice fed with a high fat diet for five months, resulted in the increase expression aand activity of PON1. ${ }^{21}$

In contrast, El-Beshbishy et al. ${ }^{22}$ failed to demonstrate a modulation on serum PON1 activity in rats supplemented with Morus alba (Egyptian mulberry) root bark extract at the dose of $500 \mathrm{mg} / \mathrm{kg} /$ day for 2 weeks. However, the positive result from the study is that the extract protected LDL from oxidation. This might be a direct effect of polyphenols on LDL itself and was not mediated by PON1 activity. Schrader et al. ${ }^{23}$ also reported that diet enriched with an isoflavone compound, genistein ( $2 \mathrm{~g} / \mathrm{kg}$ diet) which was provided for three weeks to male Wistar rats did not increase PON1 activity. The contrary results from the two studies may be because of the short duration of the intervention. The effect of polyphenols on PON expression and activity could effectively be detected if the duration of the intervention is at least 12 weeks. ${ }^{9}$

In our study, the effect that was resulted from the buni berry extract on PON1 expression was comparable to those with simvastatin, a typical lowering cholesterol drug. Statins modulate expression of PON1 gene through the interaction of sterol regulatory element binding protein (SREBP-2) with $\mathrm{Sp}^{24}$ and mitogen-activated protein kinase (MAPK) signaling cascade. ${ }^{25}$

Paraoxonase 1 is an HDL associated enzyme that is believed to have the major role in the prevention of atherosclerosis process. ${ }^{6,7}$ Polyphenolic compounds in the buni berry extract mainly anthocyanins and other polyphenolic compounds might be responsible for the effect to increase expression of PON1 mRNA. Several study in animals and human have provided evidences that polyphenolic compounds from several different fruit and plant components have increased PON1 mRNA expression and PON1 concentration. ${ }^{9}$

In daily life, free radicals from internal body metabolisms and from outer environments can cause lipid oxidation as the initial process of atherosclerosis. PON 1 enzyme as a protein component of HDL prevents HDL and LDL from oxidation. ${ }^{6}$ Through research, pathways have been postulated to explain how polyphenolic compounds can increase the expression of PON1 mRNA. Gouedard et al. showed that PON1 gene expression increased by an aryl hydrocarbon receptor-dependent mechanism, ${ }^{26}$ whereas study by Khateeb et al. reported that pomegranate juice increased PON1 expression through PPAR- $\gamma$ pathway. ${ }^{27}$

Another result from our study is that, mice feed with a high fat diet without any other intervention showed a very significant reduction in the expression of PON1 expression. This result is in agreement with the research conducted by Thomas-Moya et al. in whistar rat which showed that a high fat diet reduced the expression of PON1 mRNA and activity. ${ }^{28}$ Another research also reported that pro-atherosclerotic diet in rabbit reduced PON1 activity. ${ }^{29}$

The novelty of our research is that, it was the first intervention study that utilized the potential benefit of buni-berry (Antidesma bunius) extract in prevention of atherosclerosis process through increasing PON1 expression as an HDL associated enzyme which has the major roles in prevention and retarding lipid oxidation process. The limitation of our study is that, the intervention was performed in animal model, therefore, further research in human is recommended to determine the actual benefit of the buni-berry (Antidesma bunius) extract in prevention and retarding atherosclerosis process.

\section{CONCLUSION}

Oral administration of $300 \mathrm{mg}$ buni-berry (Antidesma bunius) extract per kg body-weight per day in 12 consecutive weeks effectively increases PON1 expression in BALB/c mice fed with a high-fat diet. Our result supports previous evidence that fruit extract with anthocyanin content and other polyphenolic compounds might effectively be used to prevent and decelerate atherosclerosis process through promoting PON1 mRNA expression and activity as an HDL associated enzyme which contributes to the prevention of lipid oxidation as the initial process of atherosclerosis. Further trials in human are needed to strengthen the evidence.

\section{ACKNOWLEDGEMENT}

We would like to thank Mr. Romi Usman, Ms. Syamsiar and Mr. Mus Gebaru (Biomolecular Laboratory) for their technical supports during 
the research. This study was supported by the Doctorate Dissertation Grant 2017 from Directorate General of Higher Education. The Ministry of Research, Technology and Higher Education of The Republic of Indonesia.

\section{CONFLICT OF INTEREST}

The authors declare no conflicts of interest.

\section{ABBREVIATIONS}

PON1: Paraoxonase 1; HDL: High Density Lipoprotein; LDL: Low Density Lipoprotein; mRNA: messenger Ribonucleic Acid.

\section{REFERENCES}

1. Basu A, Rhone M, Lyons T. Berries: emerging impact on cardiovascular health Nutr Rev. 2010;68(3):168-77.

2. Basu A, Wilkinson M, Penugonda K, Simmons B, Betts NM, Lyons TJ. Freezedried strawberry powder improves lipid profile and lipid peroxidation in women with metabolic syndrome: baseline and post intervention effects. Nutr J. 2009;8(1):43.doi:10.1186/1475-2891-8-43.

3. Rahmani $\mathrm{AH}$, Alsahli MA, Almatroodi SA. Active constituents of pomegranates (Punica granatum) as potential candidates in the management of health through modulation of biological activities. Pharmacogn J. 2017;9(5):689-95.

4. Butkhup L, Samappito S. Analysis of anthocyanains, flavonoids and phenolic acids in tropical bignay berries. Int J F Sci. 2008;8(1-2):15-34.

5. Hamidu L, Ahmad AR, Najib A. Qualitative and quantitative test of total Flavonoid buni fruit (Antidesma bunius (L.) Spreng) with UV-Vis spectrophotometry method. Pharmacogn J. 2018;10(1):60-3.

6. Singh K, Singh R, Chandra S, Tyagi S. Paraoxonase-1 is a better indicator than HDL of atherosclerosis - A pilot study in North Indian population. Diab Met Syndr: Clin Res Rev. 2018;12(3):275-8.

7. Litvinov D, Mahini D, Garelnabi M. Antioxidant and anti-inflammatory role of paraoxonase 1: Implication in atherosclerosis disease. $N$ Am J Med Sc 2012;4(11):523-32

8. Lusis AJ, Shih DM. Decreased atherosclerotic lesion formation in human serum paraoxonase transgenic mice. Circulation. 2002;106(4):484-90.

9. Martini D, Bo DC, Porrini M, Ciappellano S, Riso P. Review: Current topics : Role of polyphenols and polyphenol-rich foods in the modulation of PON1 activity and expression. J Nut Bio. 2017;48:1-8.

10. Nishina PM, Verstuyft J, Paigen B. Syntetic of low and high fat diets for the study of atherosclerosis in mouse. J Lipid Res. 1990;31(5):859-69.

11. Nicouea ENM, Savard S, Belkacemi K. Anthocyanins in Wild Blueberries of Quebec: Extraction and Identification. J Agric Food Chem. 2007;55(14):5626-35.

12. Alhakmani F, Kumar S, Khan SA. Estimation of total phenolic content, in-vitro antioxidant and anti-inflammatory activity of flowers of Moringa oleifera. Asian Pac J Trop Biomed. 2013;3(8):623-7.

13. Inácio MRC, de Lima KMG, Lopes VG, Pessoa JDC, Teixeira GHA. Total anthocyanin content determination in intact açaí (Euterpe oleracea Mart.) and palmitero-juçara (Euterpe edulis Mart.) fruit using near infrared spectroscopy (NIR) and multivariate calibration. Food Chem. 2013;136(2-4):1160-4.

14. Kedare SG, Singh RP. Genesis and development of DPPH method of antioxidant assay. J Food SciT Mechnol. 2011;48(4):412-22 .DOI 10.1007/s13197-011-0251-1.

15. Xia X, Ling W, Ma J, Xia M, Hou M, Wang Q, et al. An anthocyanin rich extract from black rice enhance atherosclerotic plaque stabilization in apolipoprotein E-deficient Mice. J Nut. 2006;136(8):2220-5.

16. Nair $A B$, Jacob $S$. A Simple practice guide for dose conversion between animals and human. J Basic Clin Pharma. 2016;7(2):27-31.

17. Sirait $\mathrm{RH}$, Hatta M, Arief $S K$, Simanjuntak TP, Suprayogi B. Profile of HMGB1 mRNA Expression and TLR4 Protein in BALB/c Mice Model Sterile Injury after Systemic Lidocaine Administration. Pharmacog J. 2018;10(3):586-9.

18. Leckey LC, Garige M, Varatharajalu R, Gong M, Nagata T, Spurney CF, et al. Quercetin and ethanol attenuate the progression of atherosclerotic plaques with concomitant up regulation of Paraoxonase1 (PON1) gene expression and PON1 Activity in LDLR-/- Mice. Alcohol Clin Exp Res. 2010;34(9):1535-42.

19. Stephens AS, Stephens SR, Morrison NA. Internal control genes for quantitative RT-PCR expression analysis in mouse osteoblasts, osteoclasts and macrophages. BMC Res Notes. 2011;4(1):410

20. Kıyıcı A, Okudan N, Gokbel H, Belviranli M. The effect of grape seed extracts on serum paraoxonase activities in streptozotocin-induced diabetic rats. J Med Food. 2010;13(3):725-8

21. Estrada-Luna D, Martinez-Hinojosa E, Cancino-Diaz JC, et al. Daily supplementation with pomegranate juice increases paraoxonase 1 expression and activity in mice fed a high-fat diet. Eur J Nutr. 2017. DOI.10.1007/s00394-017-1394-2.

22. El-Beshbishy HA, Singab ANB, Sinkkonen J, Pihlaja K. Hypolipidemic and antioxidant effects of Morus alba L.(Egyptian mulberry) root bark fractions supplementation in cholesterol-fed rats. Life Sci. 2006;78(23):2724-33.

23. Schrader C, Ernst IMA, Sinnecker $H$, Soukup ST, Kulling SE, Rimbach G. Genistein as a potential inducer of the anti-atherogenic enzyme paraoxonase-1: studies in cultured hepatocytes in vitro and in rat liver in vivo. $\mathrm{J}$ Cell Mol Med. 2012;16(10):2331-41.

24. Deakin S, Leviev I, Gernier S, James RW. Simvastatin modulates expression of the PON1 gene and increase serum paraoxonase: a role for sterol regulatory element binding protein-2. Arterioscler Thromb Vasc Biol. 2003;23(11):2083-9.

25. Arii $\mathrm{K}$, Suehiro T, Ota $\mathrm{K}$, et al. Pitavastatin induces PON1 expression through p44/42 mitogen-activated protein kinase signaling cascade in Huh7 cells. Atherosclerosis. 2009;202(2):439-45.

26. Gouedard C, Barouki R, Morel Y. Dietary polyphenols increase paraoxonase 1 gen expression by an aryl hydrocarbon receptor-dependent mechanism. Mol Cell Biol.2004;24(12):5209-22.

27. Khateeb J, Gantman A, Kreitenberg AJ, et al. Paraoxonase 1 (PON1) expression in hepatocytes is upregulated by pomegranate polyphenols: A role for PPAR- $\gamma$ pathway. Atherosclerosis. 2010;208(1):119-25.

28. Thomas-Moya E, Ganotti M, Proenza AM, Llado I. Paraoxonase response to a high-fat diet: Gender differences in the factors involved. Mol Med. 2007;13(3-4): 203-9.

29. Mackness $M$, et al. Paraoxonase activity is reduced by a pro-athersclerotic diet in rabbit. Biochem Biophys Res Commun. 2000;269(1):232-6.

Article History: Submission Date : 02-05-2018; Revised Date : 15-06-2018; Acceptance Date : 03-10-2018.

Cite this article: Tawali S, As'ad S, Hatta M, Bukhari A, Khairi N, Rifai Y, Dwiyanti R. Anthocyanin-rich Buni-berry (Antidesma bunius) Extract Increases Paraoxonase 1 Gene Expression in BALB/c Mice Fed with a High-fat Diet. J Young Pharm. 2019;11(1):46-50. 